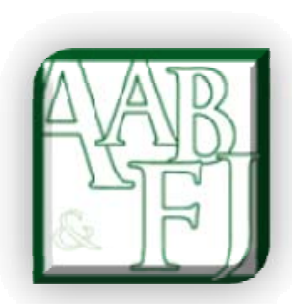

\title{
Preference in Presentation or Impression Management: A Comparison Study between Chairmen's Statements of the Most and Least Profitable Australian Companies
}

\author{
Zilan Cen ${ }^{1}$ and Rongchang Cai
}

\begin{abstract}
The purpose of this study is to investigate the extent of impression management in corporate annual reports in an Australian context. To contribute to this topic, a research question is investigated: do the most profitable Australian companies, assessed by percentage change in profit before tax, organise the chairmen's statements of their corporate annual reports and disclose information in a way that is significantly different from those least profitable companies?

In terms of the methodology, this research has selected the top 50 most and least profitable companies in ASX 500 as at 30th June 2009 respectively. For reference and comparison purposes, another 50 companies were selected randomly from the rest of the population. Content analysis was applied.

The results of this study were indicative that chairmen's letters from profitable and nonprofitable Australian companies do demonstrate significantly different presentational preferences.
\end{abstract}

JEL Classification: M40

Keywords: Impression Management, Narrative Disclosure, Chairman’s Statement, Australia

\footnotetext{
${ }^{1}$ University of Tasmania

Zilan.Cen@utas.edu.au

${ }^{2}$ University of Tasmania
} 


\section{Introduction}

Corporate annual reports are widely recognised as an important medium of communication between organisations and stakeholders (Bartlett \& Chandler 1997; Healy \& Palepu 2001; McQueen 2001). Many researchers have worked in past decades to clarify the strategies adopted for preparation of those reports (e.g. Bettman \& Weitz 1983; Dierkes \& Antal 1986; Neuet al. 1998; Prestonet al. 1996).

The purpose of this study is to assess whether the voluntary disclosure reporting strategies adopted by different companies vary according to their different financial performances. Agency theory and signalling theory are presented in this thesis as a possible explanation for any reporting discrimination that may be identified. As the sample companies used in this study were selected from the Australian Stock Exchange top 500 listed companies (ASX 500) the results will make a contribution to the Australian accounting research field.

The study was structured as follows: detailed discussion of 'impression management' and 'theories' in this field are provided before the development of the section 'research question and methodology': after the analysis in the 'results and discussion', the paper provides a summary and draws on some limitations in the ‘conclusion' section.

\section{Impression Management}

Impression management was explored to a great extent in accounting narratives. As the chairman's statements are the most widely read part of a corporate annual report (Bartlett \& Chandler 1997; Courtis 2004), they are also likely to be the most reviewed section. This study aims to look at this particular section of corporate annual reports.

The earliest work on impression management was conducted in the area of psychology. Schlenker (1980), who was among the pioneers of this area, saw impression management as a core aspect of interpersonal relations, which may be conducted consciously or unconsciously. He proposed that people tend to control perceptions in either real or imagined interactions. Since 1980 the strategy has been frequently studied in a business context. The earliest studies of impression management in business related areas took different focuses. Tweedie and Whittington (1990), for instance, exclusively studied the managerial manipulation of earnings, whereas the focus of Gardner and Martinko (1988) was on self-presentation. The latter authors conducted an observational study where audience characteristics were linked with verbal self-presentations.

To date, perhaps the most frequently used strategy to analyse impression management is content analysis. As an example of research of this kind, Smith and Taffler (2000) related self-presentational narrative disclosures with future corporate solvency. They identified and matched failed companies with financially sound companies in the same period, and performed both form and meaning orientated content analysis. The results showed that it is possible to use chairmen's statements alone to classify firms as likely to become bankrupt or financially viable in the future with a high degree of accuracy. Content analysis is also the method to be used in this research.

In some more updated UK studies, Clatworthy and Jones $(2003,2006)$ focused on the

textual characteristics of information disclosed in the 1997 chairmen's statements of the top 
and bottom 50 performing UK companies. The authors identified a series of variables to measure the textual characteristics of chairmen's statements, and found that unprofitable companies focus less on key financial indicators, quantitative or personal references in their discretionary disclosures, but tend to use more passive sentences and include more discussion about the future. These UK findings correspond with the US study of Kohut and Segars (1992) as well as of Thomas (1997), which Clatworthy and Jones $(2003,2006)$ used as the basis to identify relevant variables.

The readability of narratives forms another aspect in impression management studies. Some researchers chose to focus on variations in the readability of corporate annual reports from multiple countries to explain the situation in different cultural environments (e.g. Courtis 1995; Courtis \& Hassan 2002; Jones, 1996). However, due to their usually small sample sizes, these studies tend to provide only limited generalisation ability. Other academics tried to investigate the level of obfuscation within a particular region (Courtis, 1998; Gistet al. 2004; Linsley \& Lawrence 2007; Smith \& Taffler 1992). As Courtis (1998) purported, it is important to link readability to corporate elements such as performance, size, and industrial classification so as to study the issue of obfuscation.

The importance and benefits of research into impression management stem from several perspectives. First of all, impression management is a process initiated by the report preparers with an aim to influence the report users' investment decision making. Consequently, the study of impression management can facilitate an understanding of certain decision making patterns of report consumers. From a preparer's standpoint, ethical or not, impression management research will help identify the presentation format that is the most favourable for the company.

Secondly, impression management studies could help assess whether any subsequent decisions made by the report users as a result of reviewing the documents were severely distorted or misled. This might be of moral concern, thus might be of practical significance to legislative bodies.

\section{Theories}

In business research, top level managers (the report preparers) have been identified as acting opportunistically to maximise their personal benefits (Abrahamson \& Amir, 1994; Staw, et al. 1983). This could be explained by agency theory. Agency theory assumes that individuals behave to advantage themselves, and that every incident is driven by self-interest rather than for the good of society. In the context of corporate narrative disclosure studies, it may be construed that owners (shareholders) want to maximise their self-interests by desiring managers (report addressors) to operate the corporation in the most profitable and sustainable way, while providing a true and fair review of any achievement. However, managers tend to opportunistically obfuscate any poor performance and emphasise positive outcomes in their period-end reviews (Courtis 1998). More specifically, with regard to this study, if any significant presentational preferences were identified among most and least profitable companies, it might be the case that chairpersons from bad performing companies were distancing themselves from the suboptimal outcomes so as to minimise agency costs (e.g. Fogartyet al. 2009). 
While agency theory could explain the activities of managers from poorly performing corporations, signalling theory tends to focus on managers' behaviours in positively performing companies. Signalling theory was first proposed by Smith and Taffler (1992) and received further discussion in Rutherford (2003). Managers in prosperous companies utilise impression management in such a way that they signal their superiority through greater transparency in their disclosure of information (Merkl-Davies \& Brennan 2007). Signalling theory has gained increasing attention in reputation management, where firms seek to signal their commitment to shareholders to create a better corporate image (Toms 2002; Branco \& Rodrigues 2006). From the researcher's point of view, signalling theory may be regarded as an extension of agency theory, since it is also based on the notion of personal interests and how to avoid penalty and maximise benefit. In the context of this study, it is proposed that if presentational preference was apparent between the two groups of chairmen, signalling theory might be appropriate to explain such discrimination.

While agency theory and signalling theory are used to construct the theoretical underpinning for this particular study, legitimate theory is also a common framework used in explaining impression management, though not necessarily in this study. For instance, Deegan et al. (2000), Milne and Patten (2002) and O’Donovan (2002) considered pollution and environmental information. Ogden and Clarke (2005) investigated the disclosure strategies adopted by the privatised water industry in the UK. The authors of the latter four papers found that legitimacy theory underlay the strategic disclosures of non-routine reporting context (as opposed to corporate reports which are prepared annually or semiannually).

\section{Research Question and Methodology}

The following research question is posed based on previous research such as Clatworthy and Jones (2006).

Does the reporting strategy of Australian listed companies, as reflected in the textual characteristics of the chairmen's statements in corporate annual reports for the period ended 2009, differ significantly between those most and least profitable companies?

In order to answer this research question, eight null hypotheses were developed. A variety of measures were applied to test these hypotheses.

The findings of Kohut and Segars (1992) and Clatworthy and Jones (2006) suggest that profitable companies tend to provide lengthier reports than unprofitable ones: presumably profitable companies are more confident in discussing their past years' performance. In this regard, the length of the report constitutes a means of evaluating impression management. However, to the knowledge of the author of this study at the time of writing, there is no research evidence on this topic undertaken within the Australian context. Thus, a closer look at this issue is needed which leads to:

Ha. The chairmen's statements in corporate annual reports of the most and least profitable Australian companies are similar in length for the year ended 2009. 
Cen \& Cai | Preference in Presentation or Impression Management

For $\mathrm{Ha}$, two elements were collected: the number of words and the number of pages.

Companies with poor financial performance tend to present narratives in a way that distracts readers from this negative message (Thomas 1997). Some follow-up research has further recognised that such a rhetorical device works as a 'proxy for obfuscation' (MerklDavies \& Brennan 2007, p. 139; Pennebakeret al. 2003). The usage of passive voice is, therefore, probably an indication of poor financial performance. Whether this is true in the Australian context requires examination:

$H b$. The chairmen's statements in corporate annual reports of the most and least profitable Australian companies contain a similar percentage of passive sentences for the year ended 2009.

The proportion of passive sentences in the chairmen's statements was measured as a percentage of the total number of sentences through Microsoft Word 97.

A positive relationship between company performance and the use of personal references was also recognised by Thomas (1997). This is not surprising because profitable companies are usually more motivated to prepare their corporate annual reports in a way that engages readers in sharing the sense of successfulness. However, less profitable companies are more likely to divert readers' attention by making less use of 'we'. This finding was not confirmed by Clatworthy and Jones (2006). Further investigation of whether Thomas' (1997) conclusion was limited in generalisability is required, especially when she has only used one sample. Hc was thus developed:

Hc. The chairmen's statements in corporate annual reports of the most and least profitable Australian companies contain a similar number of personal references for the year ended 2009.

The personal preferences examined in Clatworthy and Jones (2006) were the first person singular and the first person plural including 'I, me, my, our, us and we' in the chairmen's statements recorded. This method was applied in this study by using the Find function in Microsoft Word 07.

Previous research has indicated that references to quantitative information including financial tables, trend graphs and general descriptions of market developments can be utilised as a means for impression management (e.g. Arunachalamet al. 2002; Beattie \& Jones 1999; Clatworthy \& Jones 2006). For this research, quantitative information was defined as performance-related numbers, either in absolute or percentage form following the assumptions of Clatworthy and Jones (2006). This quantitative information includes any reference to Earnings per Share (EPS), profit, sales, and dividends. Such a decision was made since there is no study in Australia that indicates which measurements are most valued by report preparers. Adopting the UK practice also enables better comparability. As supported by Clatworthy and Jones (2006), it was surmised that profitable companies will be more willing to disclose performance-related information than unprofitable companies, which led to the next hypothesis:

Hd. The chairmen's statements in corporate annual reports of the most and least profitable Australian companies contain a similar number of key financial indicators for the year ended 2009. 
The key financial indicators of profit before tax, sales, EPS and dividends were utilised in the study of Clatworthy and Jones (2006). This approach was based on the study of Beattie and Jones (1992), which showed that these four variables were deemed significant in assessing managerial performance by UK managers.

$H d$ focused on whether or not companies mentioned the key financial measurements. To further explore the use of quantitative information in the chairmen's statements of corporate annual reports of the most and least profitable companies, He was developed. He focused on the frequency of appearance of all the performance related measurements in chairmen's statements. A closer look at the frequency might be an indicator of how willing firms were to disclose their performance. In the Clatworthy and Jones (2006) study, the references were counted in two categories: monetary and percentage. In an email from one of the authors of Clatworthy and Jones (2006), the researcher clarified that this hypothesis aimed to generate a descriptive explanation in a more macro view, which examined the frequency of references of qualitative statements. As predicted by Skinner (1994) and later supported by Clatworthy and Jones (2006), profitable companies were more likely to utilise intuitive quantitative references than unprofitable ones. This discussion therefore led to a prediction here:

He. The chairman's statements in corporate annual reports of the most and least profitable Australian companies contain a similar number of quantitative references for the year ended 2009.

Another difference in discretionarily disclosed information, as confirmed by Clatworthy and Jones (2006), lay in the level of emphasis companies put upon future development. This was first proposed and evaluated by Kohut and Segars (1992). Since that time a large number of other studies have investigated the use of forward-looking information in chairmen's statements of corporate annual reports. For instance, Aljifri and Hussainey (2007) found that the extent of future information disclosure was correlated with corporate debt ratio. When reflecting on the findings of Clatworthy and Jones (2006), it seems reasonable to predict that unprofitable companies tend to divert attention away from present performance towards a well-drafted future. Consideration of these issues led to another hypothesis:

Hf. The chairman's statements in corporate annual reports of the most and least profitable Australian companies emphasize equally on the future for the year ended 2009.

Clatworthy and Jones (2006)' method of recognising chairmen's emphasis on the future in their statements was to calculate the number of words in a sentence which used the future tense, as reviewed in an email with one of the authors on $17^{\text {th }}$ August 2009.

To test what other factors are associated with the use of passive sentences in chairmen's statements, both corporate complexity and firm size were considered. It was inferred that in addition to the impact of financial performance on the presentation of chairmen's statements as Thomas (1997) recommended, the more complicated a corporate structure is and the larger the corporate size, the more issues needed be discussed in chairmen's statements. Consequently, it is more likely that the descriptions will be more conservative, since the practices of the whole company are to be reviewed. 
Cen \& Cai | Preference in Presentation or Impression Management

Hg. The chairmen's statements in corporate annual reports of Australian companies with different levels of complexity contain a similar percentage of passive sentences for the year ended 2009.

This measure was chosen because of the wide recognition that segmentation was related to more diversified business operations, and thus more complex business structures (Doukas \& Lang 2003; Hayteret al. 1999; Talhaet al. 2006). The more autonomous a division is, the more complicated a reporting setting can become, which might in turn influence the presentation of the chairmen's statements (Hax \& Majluf 1983, p.76). In order to avoid any ambiguity, this study only considered main segments as being listed on corporate annual reports, which could either be geographical or operational in nature. Where two types of segment reports were prepared by a company with no indication of which was of primary significance, the one presented first was assumed to be the main segment.

Hh. The chairmen's statements in corporate annual reports of Australian companies with different sizes contain a similar percentage of passive sentences for the year ended in 2009.

There were several measurements of firm size available in the literature, with ongoing debate on best practice found. The most commonly used measurements included logarithm of total assets (Chang \& Thomas 1989; Pandey 2004), logarithm of sales (Huang \& Song 2002; Ezeoha 2008), number of employees (Davila \& Foster, 2005; Shields 2005), and market value of the firm (Firth et al. 1996). After due consideration, the corporate market capitalisation for the 150 companies as at $30^{\text {th }}$ June 2009 was chosen to evaluate the corporate size for this particular study since it was reliable, and did not call for a complicated and excessive collection process.

The ASX 500 index as at $30^{\text {th }}$ June 2009 was utilised as a data source for the current study. The ASX 500 index contains information on the leading 500 listed companies and is publicly available. The 500 companies were seen as the population for this study. The profit before tax figures were utilised to distinguish profitable and unprofitable companies. Eightyfour companies, with either different reporting dates (such as $31^{\text {st }}$ December 2009) or which did not include chairmen's statements in their annual reports were excluded from the list for the purpose of comparison. After identifying the best 50 and worst 50 performing companies, corporate annual reports were sourced from the Aspect Huntley Annual Reports Online Database.

Other than the top 50 and bottom 50 companies identified utilising the above approach, an additional group of 50 companies was selected using the Random Function in Excel from the rest of the population to comprise a new sub-group (a middle-range group). Use of a middle-range sample aimed to strengthen the validity of the study by examining whether any trends found were continuous. Further, regardless of whether a relationship is found or not, this extension to Clatworthy and Jones (2006)' study will contribute to the existing body of knowledge.

A set of data code lists was presented in Appendix 1, developed after completing a pilot study to guide the data collection process for variables such as key financial indicators $(H d)$, quantitative references $(\mathrm{He})$ and future descriptions $(\mathrm{H} f)$. 


\section{Results and Discussion}

Table 1 presents descriptive statistics on the three sample groups. Not surprisingly, the profit after tax figures differ significantly across the three groups for the fiscal year ended in 2009 . This suggests that the three sets of companies reported on markedly different performance backgrounds. It is also interesting to note that company groups at the two extremes had smaller total market capitalisations ( $\$ 1253 \mathrm{~m}$ and $\$ 631 \mathrm{~m})$ compared to that of the middle group (\$2235m).

Table 1: Descriptive Statistics for the Three Groups of Companies Sampled

\begin{tabular}{lccccc}
\hline Company Groups & No. & Avg. Profit (\%) & Min. Profit (\%) & Max. Profit (\%) & Market Cap. (\$m) \\
Most Profitable & 50 & 776.47 & 82.38 & 14431.69 & 1253 \\
Random & 50 & 3.12 & -78.24 & 72.15 & 2235 \\
Least Profitable & 50 & -392.55 & -1812.33 & -78.91 & 631 \\
\hline
\end{tabular}

Bold figures: significance identified under 0.05 level of confidence.

\section{Length of Chairmen's Statements}

Table 2 presents descriptive statistics for the length of chairmen's statements for the most profitable, least profitable and randomly selected companies. Both the mean number of words and pages of the most profitable firms are higher than those of the least profitable firms: 923 versus 801 , and 1.80 versus 1.55 . The results of an independent two-sample t-test for the variable length are summarised in Table 3.

Table 2: Descriptive Statistics for the Length of Chairmen's Statements

\begin{tabular}{lrrrr|rrrc}
\hline & \multicolumn{4}{c|}{ Most Profitable } & \multicolumn{4}{c}{ Least Profitable } \\
& Min. & Max. & Mean & Std.dev & Min. & Max. & Mean & Std.dev \\
Length (words) & 368 & 2745 & 923 & 500 & 321 & 3317 & 801 & 502 \\
Length (pages) & 1 & 5 & 1.80 & 0.96 & 1 & 6 & 1.55 & 0.90 \\
\hline
\end{tabular}

Table 3: Significance-Test Results for Ha: Length

\begin{tabular}{ll|l|l}
\hline & Length & Most Profit. & Least Profit. \\
\hline Most Profit. & & .367 \\
& Words & .252 \\
\hline
\end{tabular}

Table 3 shows no significant relationship across the three groups relating to the length of the chairmen's statements. $\mathrm{Ha}$ is supported.

\section{Passiveness}

Table 4 presents the descriptive statistics for the percentage of passive sentences across the three groups of companies. While the mean result for the passiveness of the most profitable companies was 11.83 per cent, the figure for the least profitable companies was 15.97 per 
Cen \& Cai | Preference in Presentation or Impression Management

cent, or roughly 35 per cent higher. The average percentage of passive sentences in the random groups of companies was 11.96 per cent. It is noteworthy that the overall percentage of passive sentences across the three categories was much lower than was found by Clatworthy and Jones (2006). Although Clatworthy and Jones (2006) did not find any significant differences for the percentage of passive sentences in chairmen's statements of the most and least profitable companies, the results of this study reveal that significance does exist as Table 5 suggests: $H b$ is rejected.

Table 4: Descriptive Statistics for the Percentage of Passive Sentences

\begin{tabular}{lll|ll|ll}
\hline & \multicolumn{2}{l|}{ Most Profitable } & \multicolumn{2}{l|}{ Least Profitable } & \multicolumn{2}{l}{ Random } \\
& Mean & Std.dev & Mean & Std.dev & Mean & Std.dev \\
\hline Passive Sentences (\%) & 11.83 & 8.94 & 15.97 & 8.66 & 11.96 & 5.78 \\
\hline
\end{tabular}

Table 5: Significance-Test Results for $\boldsymbol{H b}$ (\% Passiveness)

\begin{tabular}{l|l|l}
\hline Passiveness & Most Profitable & Least Profitable \\
\hline Most Profitable & & .027 \\
\hline
\end{tabular}

Bold figures: significance identified under 0.05 level of confidence.

\section{Personal Pronouns}

Table 6 summarises the data for references to personal pronouns. Across the three categories, use of first person plurals is higher than that for first person singular constructions. Such a high plural-pronoun usage signals an attempt to engage readers and make them feel they share some responsibility in the corporate success/failure. When the singular and plural pronouns are combined, the total personal references do not differ as much for the three groups.

Table 7 shows no significant relationship across the three groups. This outcome is inconsistent with that of Clatworthy and Jones (2006). In that study the authors found that the most profitable companies were significantly more likely to use personal references overall. However, the 10 percent level of confidence used in the 2006 study might be of concern to the reliability of the test results.

Table 6: Descriptive Statistics for Personal References in Chairmen's Statements

\begin{tabular}{|c|c|c|c|c|c|c|}
\hline \multirow[t]{2}{*}{ Personal References (no.) } & \multicolumn{2}{|c|}{ Most Profitable } & \multicolumn{2}{|c|}{ Least Profitable } & \multicolumn{2}{|c|}{ Random } \\
\hline & Mean & Std.dev & Mean & Std.dev & Mean & Std.dev \\
\hline First Person Singular & 281 & 172 & 319 & 268 & 3,10 & 217 \\
\hline $\mathrm{Me}$ & 0.02 & 0.14 & 0.04 & 0.27 & 0.03 & 0.23 \\
\hline My & 0.69 & 1.13 & 0.68 & 1.01 & 0.68 & 1.01 \\
\hline Total Singular & 3.52 & N/A & 3.91 & N/A & 3.81 & N/A \\
\hline $\begin{array}{l}\text { First Person Plural } \\
\text { Our }\end{array}$ & 10.64 & 10.33 & 8.68 & 7.31 & 7.72 & 7.28 \\
\hline Us & 0.72 & 1.52 & 0.59 & 0.60 & 0.35 & 0.79 \\
\hline We & 6.88 & 7.65 & 6.55 & 6.41 & 5.69 & 5.17 \\
\hline Total Plural & 18.24 & N/A & 15.82 & $\mathrm{~N} / \mathrm{A}$ & 13.76 & $\mathrm{~N} / \mathrm{A}$ \\
\hline Total Personal References & 21.76 & N/A & 19.73 & N/A & 17.57 & N/A \\
\hline
\end{tabular}


AABFJ | Volume 8, no. 3, 2014

Table 7: Significant-Test Results for $\boldsymbol{H C}$ (Personal References)

\begin{tabular}{|c|c|c|c|}
\hline & Personal Reference & Most Profitable & Least Profitable \\
\hline Most Profitable & $\begin{array}{c}\text { I } \\
\text { Me } \\
\text { My } \\
\text { Our } \\
\text { Us } \\
\text { We } \\
\text { Total Singular } \\
\text { Total Plural } \\
\text { Total Personal Ref. }\end{array}$ & & $\begin{array}{c}0.423 \\
0.161 \\
0.518 \\
0.262 \\
0.329 \\
0.73 \\
0.617 \\
0.566 \\
0.631\end{array}$ \\
\hline
\end{tabular}

\section{Key Financial References}

Table 8 presents the descriptive statistics for references to key financial variables in the chairman's statements. Apparently, 'Profit before tax' was the least disclosed financial variable in all categories, despite its relative importance in valuing a company’s performance as recognised by Beattie and Jones (1992). In contrast, profit after tax was among the most disclosed variables regardless of the financial performance of the company. This result is once again inconsistent with the findings of the UK study (Clatworthy \& Jones 2006), where profit before tax was the most widely disclosed performance indicator and reference to profit after tax is not accounted for at all. Considering the fact that some South Pacific companies prefer using profit after tax to profit before tax as revealed in Warn (2005), such a discrepancy may derive from some cultural differences between the UK and Australia/New Zealand. Dividend is another variable that corporations are more willing to disclose in the chairmen's statements of annual reports.

Table 8: Descriptive Statistics for References to Key Financial Variables in Chairmen's Statements

\begin{tabular}{|c|c|c|c|c|c|c|c|c|c|c|c|c|c|c|c|c|c|c|}
\hline \multirow{3}{*}{$\begin{array}{l}\text { Years } \\
\text { mentioned }\end{array}$} & \multicolumn{6}{|c|}{ Most Profitable } & \multicolumn{6}{|c|}{ Least Profitable } & \multicolumn{6}{|c|}{ Random } \\
\hline & \multicolumn{2}{|c|}{ None } & \multicolumn{2}{|c|}{ '09 \& '08 } & \multicolumn{2}{|c|}{2009} & \multicolumn{2}{|c|}{ None } & \multicolumn{2}{|c|}{ '09 \& '08 } & \multicolumn{2}{|c|}{2009} & \multicolumn{2}{|c|}{ None } & \multicolumn{2}{|c|}{ '09 \& '08 } & \multicolumn{2}{|c|}{2009} \\
\hline & No. & $\%$ & No. & $\%$ & No. & $\%$ & No. & $\%$ & No. & $\%$ & No. & $\%$ & No. & $\%$ & No. & $\%$ & No. & $\%$ \\
\hline $\begin{array}{l}\text { Profit } \\
\text { before Tax }\end{array}$ & 33 & 66 & 13 & 26 & 4 & 8 & 48 & 96 & 2 & 4 & 2 & 4 & 41 & 82 & 3 & 6 & 8 & 16 \\
\hline Sales & 31 & 62 & 11 & 22 & 8 & 16 & 45 & 90 & 4 & 8 & 3 & 6 & 33 & 66 & 11 & 22 & 7 & 14 \\
\hline EPS & 30 & 60 & 15 & 30 & 6 & 12 & 46 & 92 & 4 & 8 & 1 & 2 & 40 & 80 & 6 & 12 & 9 & 18 \\
\hline Dividends & 16 & 68 & 21 & 42 & 13 & 26 & 34 & 68 & 11 & 22 & 6 & 12 & 28 & 56 & 11 & 22 & 17 & 34 \\
\hline $\begin{array}{l}\text { Profit after } \\
\text { Tax }\end{array}$ & 20 & 40 & 24 & 48 & 6 & 12 & 37 & 74 & 6 & 12 & 8 & 16 & 23 & 46 & 19 & 38 & 10 & 20 \\
\hline
\end{tabular}

As shown in Table 9, $\mathrm{Hd}$ could be rejected with confidence. Significant differences were present across all financial indicators in the chairmen's statements of the most and least profitable companies. What is more, the inclusion of a group of randomly selected companies has demonstrated a trend in decreased disclosure regarding various financial variables from most to least profitable companies. 
Cen \& Cai | Preference in Presentation or Impression Management

Table 9: Significant-Test Results for $\boldsymbol{H d}$ (Key Financial Variable)

\begin{tabular}{ll|l|l}
\hline & Key Financial Indicators & Most Profit. & Least Profit. \\
\hline Most Profitable & Profit before Tax & & .001 \\
& Sales & .002 \\
& EPS & .001 \\
& Dividend & .001 \\
& Profit after Tax & \\
\hline Least Profitable & Profit before Tax & & \\
& Sales & \\
& EPS & \\
& Dividend &
\end{tabular}

Bold figures: significance identified under 0.05 level of confidence.

\section{Quantitative References}

Table 10 provides the descriptive statistics for quantitative references in chairmen's statements for the period ended 2009. For the most profitable companies, the average number of monetary and percentage references were 8.62 and 3.45 per statement respectively. However, the large standard deviations suggest that the frequencies of quantitative references varied considerably in different chairmen's statements. The same sets of statistics for the random group were lower than those of the most profitable companies in every respect, indicating fewer references to quantitative performance-related information. Overall, the frequencies of quantitative references in this study were lower than those of Clatworthy and Jones (2006). Such a systematic difference might again be attributable to nation-specific report structuring strategies.

Table 10: Descriptive Statistics for Quantitative References in Chairmen's Statements

\begin{tabular}{l|cc|cc|cc}
\hline & \multicolumn{2}{c|}{ Most Profitable } & \multicolumn{2}{c|}{ Least Profitable } & \multicolumn{2}{c}{ Random } \\
& Mean & Std.dev & Mean & Std.dev & Mean & Std.dev \\
\hline Monetary References (no.) & 8.62 & 12.23 & 4.21 & 4.78 & 5.20 & 4.29 \\
Percentage References (no.) & 3.45 & 4.65 & 1.98 & 3.21 & 2.86 & 2.99 \\
\hline
\end{tabular}

Table 11: Significant-Test Results for $\boldsymbol{H e}$ (Quantitative References)

\begin{tabular}{ll|l|l}
\hline & Quantitative Reference & Most Profitable & Least Profitable \\
\hline Most Profitable & Monetary (\$) & & .028 \\
& Percentage (\%) & .027 \\
\hline \hline
\end{tabular}

Bold figures: significance identified under 0.05 level of confidence.

He should be rejected according to Table 11 .

\section{Emphasis on the Future}

Table 12 reveals that the most profitable companies used approximately 70 words to describe their plans for the future in their chairman's statements. This number climbs up to 105 words for random companies, and an extreme 122 words per statement for the least profitable companies. The small standard deviation of the most profitable companies indicates that the data do not vary greatly within the group, whereas the much higher standard deviations for 
AABFJ | Volume 8, no. 3, 2014

the other two categories signal a much more scattered data distribution. $H f$ is rejected according to Table 13.

Table 12: Descriptive Statistics for Emphasis on the Future in Chairmen's Statements

\begin{tabular}{|c|c|c|c|c|c|c|}
\hline & \multicolumn{2}{|c|}{ Most Profitable } & \multicolumn{2}{|c|}{ Least Profitable } & \multicolumn{2}{|c|}{ Random } \\
\hline & Mean & Std.dev & Mean & Std.dev & Mean & Std.dev \\
\hline Future words (no.) & 69.7 & 32.23 & 121.88 & 77.33 & 105.21 & 90.81 \\
\hline
\end{tabular}

Table 13: Results of Tests of Significance for $\boldsymbol{H f}$ (Emphasis on the Future)

\begin{tabular}{l|l|l}
\hline Reference to Future & Most Profitable & Least Profitable \\
\hline Most Profitable & & .000 \\
\hline
\end{tabular}

Bold figures: significance identified under 0.05 level of confidence.

Segmentation and Market Capitalisation

To consider whether factors other than profitability affect the quantity of passive sentences in chairman's statements, bivariate correlation tests have been performed. The results are summarised below in Table 14.

Table 14: Correlation-Test Results for $\boldsymbol{H g}$ and $\boldsymbol{H}$ (Segmentation and Market Capitalisation)

\begin{tabular}{l|c|c}
\hline Correlation & Complexity & Size \\
\hline Passiveness & $\mathbf{. 0 1 9}$ & .142 \\
\hline
\end{tabular}

Bold figures: significance identified under 0.05 level of confidence.

It appears that the complexity of corporations is correlated to the level of passive sentences in chairmen's statements, regardless of the profitability of the companies (0.019). However, a significant correlation was not found between the passiveness and corporate size (0.142). Therefore, $\mathrm{Hg}$ was rejected while $\mathrm{Hh}$ was supported. Although no literature was found that made reference to the relationship between corporate complexity and the degree of passiveness in corporate communication vehicles to the knowledge of the author, this finding might be interesting to explore further in future work.

The test results for the current study and those of Clatworthy and Jones (2006) are summarised in Table 15. The five rejected hypotheses are powerful in showing that there are some systematic differences in the textual characteristics of information in the chairmen's statements of the most and least profitable companies in Australia. Perhaps one of the most profound results of this study is the identification of the trends that as the progress in profitability increases, companies do tend to disclose more financial indicators to emphasise positive outcomes. 
Cen \& Cai | Preference in Presentation or Impression Management

Table 15: Summary of Hypotheses Testing

\begin{tabular}{c|c|c|c|c|c|c|c|c}
\hline Hypotheses & $\boldsymbol{H a}$ & $\boldsymbol{H b}$ & $\boldsymbol{H c}$ & $\boldsymbol{H d}$ & $\boldsymbol{H e}$ & $\boldsymbol{H} \boldsymbol{f}$ & $\boldsymbol{H} \boldsymbol{g}$ & $\boldsymbol{H h}$ \\
\hline $\begin{array}{c}\text { Current Study } \\
\begin{array}{c}\text { Clatworthy \& Jones } \\
(2006)\end{array}\end{array}$ & Support & Reject & Support & Reject & Reject & Reject & Reject & Support \\
\hline
\end{tabular}

By informing readers how positive the year has been through the disclosure of multiple performance indicators, the chairmen are signalling that their corporations offer better information transparency. The readers are therefore easier to convince that investing in those corporations may generate better outcomes, since they are informed specifically what is going on backstage and how the investments have been managed. In this regard, such an approach of signalling good news is an obvious application of signalling theory.

Accordingly, the explanation as to why those companies with suboptimal performances chose not to reveal as much performance-related information was because that they believed the company (or themselves if agency theory is assumed) would be disadvantaged if they chose to do so. Such a disadvantage might reduce shareholder numbers, violate company reputation, reduce market capitalisation, or diminish financial returns of management-level employees. The more unsatisfactory performance indicators were disclosed in the reports, the more the interests of the parties would be jeopardised. It also shows that the chairmen of those companies would rather sacrifice stakeholders' interest in understanding what has happened in exchange for more acceptable potential future returns. In other words, it is rational to declare that agency theory and signalling theory could provide appropriate explanations towards the results of this study.

\section{Conclusion}

One purpose of this study was to find out if the textual differences in chairmen's statements of the most and least profitable companies are apparent in Australia. In pursuing this question, the author has developed a set of hypotheses. Six of the hypotheses were similar to those of an earlier study (Clatworthy \& Jones 2006), while the other two were developed for the current study to extend upon this work.

With five out of eight hypotheses being rejected, it is reasonable to infer that there is some systematic difference in the textual characteristics of information disclosed in chairmen's statements of the most and least profitable Australian companies.

From a theoretical perspective, the significant test results have provided evidence that information concealment or exaggeration does occur in Australian chairmen's statements, and that it is explainable by agency theory and signalling theory.

This study highlights the ubiquitous trend of impression management in corporate annual reports, especially in chairmen's statements - the discretionary disclosure section. As there are no studies known to the researcher that specifically examined the textual characteristics of annual reports of Australian listed companies, this study serves to encourage horizontal comparisons to other similar international studies such as Clatworthy and Jones (2006). Also, considering the timing of the related studies, this study also enables 
longitudinal comparisons, which may provide some evidence of how trends in disclosure and application of impression management are developing in the discretionary section of corporate annual reports.

Another contribution of this study regards the introduction of a middle group for comparison purposes. Consider the study of Clatworthy and Jones (2006) and most of the studies of this kind, where only samples at the two extremes of profitability were compared and analysed. By introducing the randomly selected middle group, it is apparent that at least with some variables, clear trends have been demonstrated along the profitability axis.

Finally, this study has also shown that the employment of passive voice in chairmen's statements is not only related to the extent of increase in corporate profit, but also to its level of corporate complexity as represented by the number of segments.

In terms of the limitations, unlike Clatworthy and Jones (2006)' approach where almost all UK registered companies were considered, the population of this study consisted of the ASX 500 companies only. Thus the study results may have limited representability, especially to those companies on a smaller scale. This weakness could be mitigated by expanding the population to account for all Australian listed companies.

Another possible restriction to generalisability is the time period for the data. In the current study, data were collected for only one year. Better generalisability could be achieved by taking a longitudinal study to expand the time period concerned.

One future research opportunity lies in the relationship between variable disclosures and corporate profitability. It is merely established in Clatworthy and Jones (2006) and the present study that the most and least profitable companies do behave in significantly different manners, in association with the disclosure of some variables. However, whether there is a causal relationship remains unanswered. By identifying factors that might lead to the disclosure of certain variables or certain disclosure strategies, a better understanding of the underlying meaning of corporate annual reports could be achieved.

\section{References}

Abrahamson, E \& Amir, E 1994, 'Concealment of negative organizational outcomes: An agency theory perspective’, Accounting and Business Research, vol. 37, no. 5, pp. 13021334.

Aljifri, H \& Hussainey, K 2007, 'The determinants of forward-looking information in annual reports of UAE companies’, Managerial Auditing Journal, vol. 22, no. 9, pp. 881-891. http://dx.doi.org/10.1108/02686900710829390

Arunachalam, V, Pei, B \& Steinbart, P 2002, 'Impression management with graphs: effects on choices', Journal of Information Systems, vol. 16, no. 2, pp. 183-202. http://dx.doi.org/10.2308/jis.2002.16.2.183

Bartlett, S \& Chandler, R 1997, 'The corporate report and the private shareholder: Lee and Tweedie twenty years on', British Accounting Review, vol. 29, no. 3, pp. 245-261. http://dx.doi.org/10.1006/bare.1996.0044

Beattie, V \& Jones, M 1992, 'The use and abuse of graphs in annual reports: a theoretical framework and an empirical study', Accounting and Business Research, vol. 22, no. 88, pp. 291-303. 
Beattie, V \& Jones, M 1999, 'Australian financial graphs: an empirical study', Abacus, vol. 35, no. 1, pp. 46-76. http://dx.doi.org/10.1111/1467-6281.00034

Bettman, J \& Weitz, B 1983, 'Attributions in the board room: casual reasoning in corporate annual reports’, Administrative Science Quarterly, vol. 28, no. 2, pp.165-183. http://dx.doi.org/10.2307/2392616

Branco, MC \& Rodrigues, LL 2006, 'Corporate social responsibility and resource-based perspectives', Journal of Business Ethics, vol. 69, pp. 111-132. http://dx.doi.org/10.1007/s10551-006-9071-z

Chang, Y \& Thomas, H 1989, 'The impact of diversification strategy on risk-return performance', Strategic Management Journal, vol. 10, no. 3, pp. 271-284. http://dx.doi.org/10.1002/smj.4250100306

Clatworthy, M \& Jones, M 2003, 'Financial reporting of good and bad news: evidence from accounting narratives', Accounting and Business Research, vol. 33, no. 3, pp. 171-185.

Clatworthy, M \& Jones, M 2006, 'Differential patterns of textual characteristics and company performance in the chairman's statement', Accounting, Auditing and Accountability Journal, vol. 19, no. 4, pp. 493-511. http://dx.doi.org/10.1108/09513570610679100

Courtis, JK 1995, 'Readability of annual reports: Western versus Asian evidence', Accounting, Auditing and Accountability Journal, vol. 8, no. 2, pp. 4-17. http://dx.doi.org/10.1108/09513579510086795

Courtis, JK 1998, 'Annual report readability variability: Tests of the obfuscation hypothesis', Accounting, Auditing and Accountability Journal, vol. 11, no. 4, pp. 459-471. http://dx.doi.org/10.1108/09513579810231457

Courtis, JK \& Hassan, S 2002, 'Reading ease of bilingual annual reports', The Journal of Business Communication, vol. 39, no. 4, pp. 394-413. http://dx.doi.org/10.1177/002194360203900401

Courtis, JK 2004 'Corporate report obfuscation: Artefact or phenomenon?', British Accounting Review, vol. 36, no. 3, pp. 291-312. http://dx.doi.org/10.1016/j.bar.2004.03.005

Davila, A \& Foster, G 2005, 'Management accounting systems adoption decisions: Evidence and performance implications from early-stage/startup companies', The Accounting Review, vol. 80, no. 4, pp. 1039-1068. http://dx.doi.org/10.2308/accr.2005.80.4.1039

Deegan, C, Rankin, M \& Voght, P 2000, 'Firm's disclosure reactions to major social incidents: Australian evidence', Accounting Forum, vol. 24, no. 1, pp. 101-130. http://dx.doi.org/10.1111/1467-6303.00031

Dierkes, M \& Antal, B 1986, 'Whither corporate social reporting? Is it time to legislate?', California Management Review, vol. 28, no. 3, pp. 106-121. http://dx.doi.org/10.2307/41165205

Doukas, JA \& Lang, L 2003, 'Foreign direct investment, diversification and firm performance', Journal of International Business Studies, vol. 34, pp. 153-172. http://dx.doi.org/10.1057/palgrave.jibs.8400014

Ezeoha, AE 2008, 'Firm size and corporate financial-leverage choice in a developing economy; Evidence from Nigeria’, The Journal of Risk Finance, vol. 9, no. 4, pp. 351363. http://dx.doi.org/10.1108/15265940810895016 
Firth, M, Lohne, J, Ropstad, R, \& Sjo, J 1996, 'The remuneration of CEOs and corporate financial performance in Norway', Managerial and Decision Economics, vol. 17, no. 3, pp. 291-301. http://dx.doi.org/10.1002/(SICI)1099-1468(199605)17:3<291::AIDMDE752>3.0.CO;2-X

Fogarty, T, Magnan, ML, Markarian, G, \& Bohdjalian, S 2009, 'Inside agency: The rise and fall of Nortel', Journal of Business Ethics, vol. 84, no. 1, pp. 165-187. http://dx.doi.org/10.1007/s10551-008-9680-9

Gardner, W, \& Martinko, M 1988, 'Impression management in organizations', Journal of Management, vol. 14, no. 2, pp. 321-338. http://dx.doi.org/10.1177/014920638801400210

Gist, WE, McClain, G, \& Shastri, T 2004, 'User versus auditor perceptions of the auditor's report on internal control: Readability, reliability and auditor legal liability', American Business Review, vol. 22, no. 2, pp. 117-130.

Hax, AC, \& Majluf, NS 1983, 'Organization design: A case study on matching strategy and structure', Journal of Business Strategy, vol. 2, no. 4, pp. 72-86. http://dx.doi.org/10.1108/eb039024

Hayter, R, Patchell, J, \& Rees, K 1999, 'Business segmentation and location revisited: Innovation and the terra incognita of large firms', Regional Studies, vol. 33, no. 5, pp. 425-442. http://dx.doi.org/10.1080/00343409950081275

Healy, P \& Palepu, K 2001, 'Information asymmetry, corporate disclosure, and the capital markets: A review of the empirical disclosure literature', Journal of Accounting and Economics, vol. 31, no. 1-3, pp. 405-440. http://dx.doi.org/10.1016/S0165-4101(01)00018-0

Huang, SGH \& Song, FM 2002, 'The determinants of capital structure: evidences from China', working paper, School of Economics and Finance and Centre for China Financial Research.

Jones, M 1996, 'Readability of annual reports: Western versus Asian evidence - a comment to contextualize', Accounting, Auditing and Accountability Journal, vol. 9, no. 2, pp. 86104. http://dx.doi.org/10.1108/09513579610116376

Kohut, G \& Segars, A 1992, 'The president's letter to stockholders: An examination of corporate communication strategy', Journal of Business Communication, vol. 29, no. 1, pp. 7-21. http://dx.doi.org/10.1177/002194369202900101

Linsley, PM \& Lawrence, MJ 2007, 'Risk reporting by the largest UK companies: Readability and lack of obfuscation', Accounting, Auditing and Accountability Journal, vol. 20, no. 4, pp. 620-641. http://dx.doi.org/10.1108/09513570710762601

McQueen, R 2001, 'The corporate image: the regulation of annual reports in Australia', Macquarie Law Journal, vol. 1, no. 1, pp. 93-128.

Merkl-Davis, D \& Brennan, N 2007, 'Discretionary disclosure strategies in corporate narratives: Incremental information or impression management?’, Journal of Accounting Literature, vol. 26, pp. 116-194.

Milne, M \& Patten, D 2002, 'Securing organizational legitimacy: An experimental decision case examining the impact of environmental disclosures', Accounting, Auditing and Accountability Journal, vol. 15, no. 3, pp. 372-405. 
Cen \& Cai | Preference in Presentation or Impression Management

http://dx.doi.org/10.1108/09513570210435889

Neu, D, Warsame, H \& Pedwell, K 1998, 'Managing public impressions: Environmental disclosures in annual reports', Accounting, Organizations and Society, vol. 17, pp. 645665. http://dx.doi.org/10.1016/0361-3682(92)90017-M

O’Donovan, G 2002, 'Environmental disclosures in the annual report', Accounting, Auditing and Accountability Journal, vol. 15, no. 3, pp. 344-371.

http://dx.doi.org/10.1108/09513570210435870

Ogden, S \& Clarke, J 2005, 'Customer disclosures, impression management and the construction of legitimacy: Corporate reports in the UK privatised water industry', Accounting, Auditing and Accountability Journal, vol. 18, no. 3, pp. 313-345. http://dx.doi.org/10.1108/09513570510600729

Pandey, M 2004, 'Capital structure, profitability and market structure: Evidence from Malaysia’, Asia Pacific Journal of Economics and Business, vol. 8, no. 2, pp. 78-91.

Pennebaker, JW, Mehl, MR \& Niederhoffer, K 2003, 'Psychological aspects of natural language use: Our words, our selves’, Annual Review of Psychology, vol. 54, pp. 547577. http://dx.doi.org/10.1146/annurev.psych.54.101601.145041

Preston, A, Wright, C \& Young, J 1996, 'Imaging annual reports', Accounting, Organizations and Society, vol. 21, no. 1, pp. 113-137. http://dx.doi.org/10.1016/0361-3682(95)00032$\underline{5}$

Rutherford, BA 2003, 'Obfuscation, textual complexity and the role of regulated narrative accounting disclosure in corporate governance', Journal of Management and Governance, vol. 7, pp. 187-210. http://dx.doi.org/10.1023/A:1023647615279

Schlenker, B 1980, Impression management: The self-concept, social identity, and interpersonal relations, 1 st edn, Monterey, California.

Shields, J 2005, 'Revenue management: A strategy for increasing sales revenue in small businesses', Journal of Small Business Strategy, vol. 16, no. 2, pp. 43-53.

Skinner, D 1994, 'Why firms voluntarily disclose bad news', Journal of Accounting Research, vol. 32, no. 1, pp. 38-60. http://dx.doi.org/10.2307/2491386

Smith, M \& Taffler, R 1992, 'The chairman's report and corporate financial performance', Accounting and Finance, vol. 32, pp. 75-90.

http://dx.doi.org/10.1111/j.1467-629X.1992.tb00187.x

Smith, M \& Taffler, R 2000, 'The chairman's statement: a content analysis of discretionary narrative disclosure', Accounting, Auditing and Accountability Journal, vol. 13, no. 5, pp. 624-646. http://dx.doi.org/10.1108/09513570010353738

Staw, B, McKechnie, P \& Puffer, S 1983, 'The justification of organizational performance', Administrative Science Quarterly, vol. 28, pp. 582-600.

http://dx.doi.org/10.2307/2393010

Talha, M, Sallehhuddin, A \& Mohammad, J 2006, 'Changing pattern of competitive disadvantage from disclosing financial information: A case study of segmental reporting practice in Malaysia', Managerial Auditing Journal, vol. 21, no. 3, pp. 265-274. http://dx.doi.org/10.1108/02686900610653008

Thomas, J 1997, 'Discourse in the marketplace: the making of meaning in annual reports', The Journal of Business Communication, vol. 34, no. 1, pp. 47-66. 
AABFJ | Volume 8, no. 3, 2014

http://dx.doi.org/10.1177/002194369703400103

Toms, JS 2002, 'Firm resources, quality signals, and the determinants of corporate environmental reputation: Some UK evidence', British Accounting Review, vol. 34, pp. 257-282. http://dx.doi.org/10.1006/bare.2002.0211

Tweedie, D \& Whittington, G 1990, 'Financial reporting: current problems and heir implications for systematic reform', Accounting and Business Research, vol. 21, no. 81, pp. 87-102.

Warn, J 2005, 'Intangibles in commercialisation: the case of air navigation services in the South Pacific', Journal of Intellectual Capital, vol. 6, no. 1, pp. 72-88.

http://dx.doi.org/10.1108/14691930510574672 
Cen \& Cai | Preference in Presentation or Impression Management

\section{Appendix 1}

Data Code Book - Quantitative References

\begin{tabular}{l|l}
\hline $\begin{array}{l}\text { Categories of Information NOT Qualified for } \\
\text { Quantitative References }\end{array}$ & Examples \\
\hline Describing production capacity & “expansion capacity to 21000 tonnes pa” \\
Describing market demand & "4.7 million ounces” \\
Tax rate & " $30 \%$ tax rate” \\
Franking rate & "40\% franked” \\
Exchange rate & "USD/AUD is 0.7 \\
Investment strategy & “ 10 million on-market buy-back” \\
Operational strategy & "a $30 \%$ joint venture farm-in agreement” \\
\hline
\end{tabular}

\section{Data Code Book - Key Financial Indicators}

\begin{tabular}{l|l}
\hline Key Financial Indicators & Examples Suggesting Possible References \\
\hline Profit after Tax & Profit after tax \\
& Net profit \\
& Net operating profit, etc \\
\hline Profit before Tax & Profit before tax \\
& Net profit \$ ... with tax \$ \\
& Operating profit before tax, etc \\
\hline Sales & Sales \\
& Revenues \\
& Income, etc \\
\hline EPS & EPS \\
& Earnings per share \\
& Earnings per unit (of share) \\
& Distributable income per share, etc \\
\hline Dividend & Dividend \\
& Distribution per unit, etc \\
\hline
\end{tabular}

Data Code Book - Future Descriptions

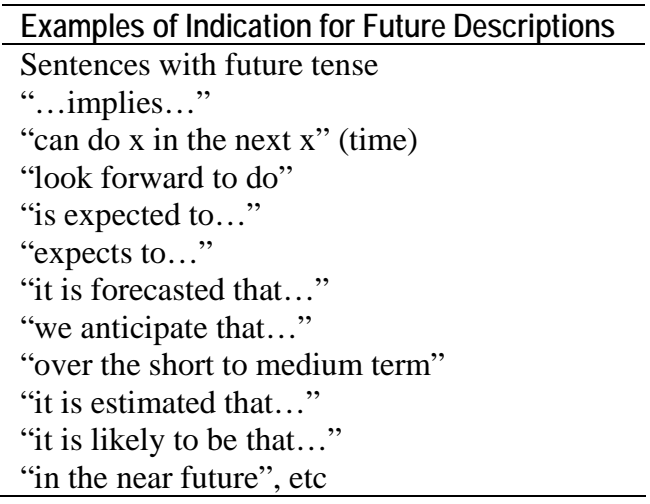


AABFJ | Volume 8, no. 3, 2014 